\title{
EFFECTS OF IRRIGATION AMOUNT AND TIMING ON ALFALFA Nutritive VALUE
}

\author{
J. Holman, D. Min, N. Klocke, I. Kisekka, R. Currie
}

\begin{abstract}
Most hay producers in southwest Kansas irrigate their alfalfa (Medicago sativa L.) because precipitation is insufficient for profitable rainfed production. However, water supplies in the central Great Plains are dwindling, particularly in the central and southern Ogallala Aquifer region. Irrigating many field crops in this region, including alfalfa, is therefore becoming a challenge. We determined the effects of irrigation quantity and timing on alfalfa forage nutritive value during a five-year field study of alfalfa in southwest Kansas. Nutritive value was quantified in the form of crude protein, acid detergent fiber, neutral detergent fiber, total digestible nutrients, and relative feed value. In general, applying the highest amount of irrigation $1610 \mathrm{~mm}$ during the growing season) resulted in the lowest forage nutritive value compared to lower amounts of irrigation (0, 200, and $380 \mathrm{~mm}$ irrigation). Nutritive value concentrations $\left(\mathrm{g} \mathrm{kg}^{-1}\right)$ under full irrigation averaged 211 for crude protein, 316 for acid detergent fiber, and 422 for neutral detergent fiber, while concentrations $\left(\mathrm{g} \mathrm{kg}^{-1}\right)$ in rainfed production averaged 225 for crude protein, 247 for acid detergent fiber, and 370 for neutral detergent fiber. Alfalfa nutritive value was not affected whether the same amount of irrigation water was applied either before green-up and between each cutting, or before green-up and between all cuttings except between cuttings 2 and 3. However, there was a tendency for lower forage nutritive value at the fourth cutting when irrigation was withheld between cuttings 2 and 3, and that saved water was added to the amount of irrigation applied to the fourth cutting. When averaged over irrigation treatments, alfalfa nutritive value was lower from the first and second cuttings than from the third and fourth cuttings. Annual yields, averaged over years, declined from $1.53 \mathrm{~kg} \mathrm{~m}^{-2}$ with $610 \mathrm{~mm}$ of irrigation to $0.43 \mathrm{~kg} \mathrm{~m}^{-2}$ for rainfed production. Annual yields were the same when irrigation was distributed over the growing season or withheld between the second and third cuttings. Irrigation amounts less than full crop requirement resulted in a 13\% higher dollar value product based on relative feed value, but decreasing irrigation from 610 to $380 \mathrm{~mm}$ reduced yield by 19\%.
\end{abstract}

Keywords. Alfalfa, Cattle, Forage quality, Irrigation, Livestock, Nutritive value, Water.

$\mathrm{A}$ lfalfa (Medicago sativa L.) is an important forage crop in the Great Plains as well as many other parts of the world for dairy and cattle feeding industries. For 2015, alfalfa was the only crop projected to be profitable under irrigation in southwest Kansas, averaging a net return of $\$ 326 \mathrm{ha}^{-1}$ (Ibendahl et al., 2015). Although not always the case, most other irrigated crops such as corn, grain sorghum, soybeans, wheat, corn silage, and sorghum silage all had negative cash flow projections. Most alfalfa is irrigated in the central Great Plains, but water supplies are dwindling, particularly in central and southern Ogallala Aquifer region, where withdrawals exceed average annual aquifer recharge. Irrigating many field crops in this region, including alfalfa, is therefore becoming a challenge.

Submitted for review in July 2015 as manuscript number NRES 11456; approved for publication by the Natural Resources \& Environmental Systems Community of ASABE in April 2016.

Contribution No. 14-390-D from the Kansas Agricultural Experiment Station.

The authors are Johnathon Holman, Associate Professor, Kansas State University Southwest Research-Extension Center (SWREC), Garden City, Kansas; Doo-Hong Min, Assistant Professor, Department of Agronomy, Kansas State University, Manhattan, Kansas; Norman Klocke, ASABE Member, Professor Emeritus, Isaya Kisekka, ASABE Member, Assistant Professor, and Randall Currie, Associate Professor, Kansas State University SWREC, Garden City, Kansas. Corresponding author: Johnathon Holman, Kansas State University SWREC, 4500 E. Mary St., Garden City, KS 67846; phone: 620-276-8286; e-mail: jholman@ksu.edu.
Thus, the profitability of growing alfalfa relies heavily on how much irrigation can be applied, and how effectively alfalfa uses the applied water. Several studies have reported on the effects of irrigation amount and timing on alfalfa yield and potential economic return (Abdul-Jabbar et al., 1985; Bolger et al., 1990; Retta and Hanks, 1980; Frate et al., 1991; Klocke et al., 2003, 2013). These studies found that alfalfa yield was linearly correlated to crop evapotranspiration $\left(\mathrm{ET}_{c}\right)$, i.e., evapotranspiration from disease-free, well-fertilized crops, grown in large fields, under optimum soil water conditions, and achieving full production under the given climatic conditions (Allen et al., 1998), but nutritive value was often not reported. Yield results from this study were reported previously by Klocke et al. (2013), who found that alfalfa yield increased from $4.3 \mathrm{Mg} \mathrm{ha}^{-1}$ for rainfed production to $15.3 \mathrm{Mg} \mathrm{ha}^{-1}$ with $610 \mathrm{~mm}$ of irrigation (representing the maximum water allocation in Kansas) during the growing season. This article reports on the effect of irrigation amount and timing on alfalfa nutritive value.

Forage nutritive value can be affected by many factors, including development stage at harvest (Kalu and Fick, 1983), climate (i.e., high temperature and drought), soil fertility, insects (Hutchins et al., 1989; Flinn et al., 1990; Hansen et al., 2002; Sulc et al., 2004), weeds (Temme et al., 1979), and carbon dioxide level (Baslam et al., 2013). Many research projects have evaluated drought effects on forage 
yield and nutritive value in forage legumes (Gifford and Jensen, 1967; Foulds, 1978; Stroth et al., 1972; Fairbourn, 1982; Smith et al., 1986; Marten et al., 1987). Forage nutritive value in alfalfa was usually higher with water stress than without water stress (Vough and Marten, 1971; Snaydon, 1972; Carter and Sheaffer, 1983; Harmoney et al., 2013, Peterson et al., 1992). This study uniquely adds to the database of information on alfalfa nutritive value by reporting results across a complete range of $\mathrm{ET}_{c}$ from fully irrigated to dryland for a complete five-year life-cycle of the crop. In addition, this study compares distributing irrigation over the growing season and withholding irrigation between the second and third cuttings, which is a period of higher temperature stress and $\mathrm{ET}_{c}$.

The objectives of this study were to evaluate the effects of different irrigation amounts and timing on forage nutritive values, i.e., crude protein (CP), acid detergent fiber (ADF), neutral detergent fiber (NDF), total digestible nutrients (TDN), and relative feed value (RFV) for a five-year field study of alfalfa in southwest Kansas. Alfalfa yield and stand life were reported in a previous article (Klocke et al., 2013).

\section{MATERIALS AND MethodS \\ EXPERIMENTAL SITE}

This research was conducted at the Kansas State University Southwest Research-Extension Center (SWREC) near Garden City, Kansas ( $38^{\circ} 1^{\prime} 9^{\prime \prime} \mathrm{N}, 100^{\circ} 49^{\prime} 16^{\prime \prime} \mathrm{W}, 887 \mathrm{~m}$ above mean sea level). The soil type at the study site was a deep, well drained Ulysses silt loam (fine-silty, mixed, mesic Aridic Haplustoll) with soil $\mathrm{pH}$ range of 8.1 to 8.3. The silt loam soil extended to the depth of soil water measurements $(2.4 \mathrm{~m})$, but the available water capacity from the surface to $1.07 \mathrm{~m}$ deep was $0.18 \mathrm{~m} \mathrm{~m}^{-1}$ between field capacity (volumetric water content of $33 \%$ ) and permanent wilting (volumetric water content of $15 \%$ ) and $0.12 \mathrm{~m} \mathrm{~m}^{-1}$ from 1.07 to $2.44 \mathrm{~m}$ deep between field capacity (volumetric water content of $27 \%$ ) and permanent wilting (volumetric water content of $15 \%$ ). The semi-arid climate of the study site had a long-term (1981-2010) average annual precipitation of $489 \mathrm{~mm}$, mean summer growing season daytime high temperature of $29^{\circ} \mathrm{C}$ (30-year average, May through August), open pan evaporation (April through September) of $1810 \mathrm{~mm}$, and a frost-free period of 170 days. During the study (2007-2011), the average annual precipitation was $429 \mathrm{~mm}$, and reference ET $\left(\mathrm{ET}_{r}\right)$ was $1558 \mathrm{~mm}$, calculated with an alfalfa-modified Penman model (Kincaid and Heermann, 1974; Lamm et al., 1994) using weather factors including maximum and minimum air temperature, relative humidity, solar radiation, and wind run (wind speed $\times$ time) from an automated weather station near the study site.

\section{IRRIGATION SYSTEM AND MANAGEMENT}

A commercial four-span (44 m span width) linear-move sprinkler system (model 8000, Valmont Corp., Valley, Neb.) was modified to deliver water in any combination of irrigated treatments during an irrigation event (Klocke et al., 2003). The irrigation plots were $13.7 \mathrm{~m}$ wide and $27.4 \mathrm{~m}$ long. Net application depth (i.e., the water reaching the soil surface) was $25 \mathrm{~mm}$ with a uniformity of 0.90 for every irrigation event on all treatments. The net application depth and uniformity of application were confirmed with "catch can" tests (ASABE, 2012). A cluster of spray nozzles with $41 \mathrm{kPa}$ pressure regulators were installed at a height of $2.1 \mathrm{~m}$ above the ground in a setup known as MESA (mid-elevation spray application). The MESA design allowed for achieving high uniformity since the irrigation system was set up to irrigate multiple crops including corn, sorghum, wheat, and sunflower. With each pass of the irrigation system, an irrigation treatment was irrigated or not irrigated to achieve the irrigation variable (tables 1 and 2). The time between irrigation events led to the differences in irrigation amount among irrigation treatments. No more than two irrigation events $(50 \mathrm{~mm})$ per week were applied in irrigation treatment 1 , which received the most irrigation, to simulate the irrigation capacity $\left(7.3 \mathrm{~mm} \mathrm{~d}^{-1}\right)$ of commercial systems with adequate well yields in the region (Klocke et al., 2013).

The experimental design was a randomized complete block with four replications. The protocol for irrigation timing and amount was intended to provide yield responses from irrigation within the context of best management practices for alfalfa production (table 1). Three of the six irrigation treatments were designed to apply water in accordance with local standard practices (treatments 1,2, and 5), where irrigation was provided between green-up and the first cutting and between the remaining cuttings. Treatments 2 and 3 received $380 \mathrm{~mm}$, while treatments 4 and 5 received $200 \mathrm{~mm}$. Instead of spreading irrigation events over the whole growing season, irrigation was withheld from treatments 3 and 4 between cuttings 2 and 3. Irrigation may be more effective during other parts of the growing season because temperatures are typically higher between cuttings 2 and 3 , which would reduce yield potential. The sixth treatment received no irrigation during the study.

An irrigation scheduling template was formulated as a starting point for timing irrigation events during the growing season (table 2). This template was used for 2009-2011, when alfalfa was cut four times because of very limited regrowth after cutting 4 , but a similar template was used in 2007 and 2008, when alfalfa was cut five times. Treatment 1 was allocated a maximum of $610 \mathrm{~mm}$, which is equal to the maximum authorized irrigation in one year for the oldest water rights in Kansas. Six irrigation events were scheduled for treatment 1 before each cutting due to the system capacity limitation that no more than two events could be applied in a week, leaving approximately one week for cutting and harvesting. This limitation was based on the typical pumping capacity of wells in southwest Kansas, which is declining

Table 1. Protocol for total irrigation during growing season at Kansas State University SWREC near Garden City, Kansas, from 2007 through 2011.

\begin{tabular}{ccl}
$\begin{array}{c}\text { Irrigation } \\
\text { Treatment }\end{array}$ & $\begin{array}{c}\text { Total } \\
\text { Irrigation } \\
(\mathrm{mm})\end{array}$ & Irrigation Timing \\
\hline 1 & 610 & After green-up and between all cuttings \\
2 & 380 & After green-up and between all cuttings \\
3 & 380 & None between cuttings 2 and 3 \\
4 & 200 & None between cuttings 2 and 3 \\
5 & 200 & After green-up and between all cuttings \\
6 & 0 & None \\
\hline
\end{tabular}


Table 2. Irrigation application protocol by irrigation treatment and cutting at Kansas State University SWREC near Garden City, Kansas, from 2007 through 2011 (all values are in $\mathbf{m m}$ ).

\begin{tabular}{|c|c|c|c|c|c|c|c|c|c|c|c|c|c|c|c|}
\hline \multirow{2}{*}{$\begin{array}{l}\text { Irrigation } \\
\text { Treatment }\end{array}$} & \multicolumn{7}{|c|}{ Before Cutting 1} & \multicolumn{7}{|c|}{ Between Cuttings 1 and 2} & \multirow{2}{*}{$\begin{array}{c}\text { Seasonal } \\
\text { Total }\end{array}$} \\
\hline & 1 & 2 & 3 & 4 & 5 & 6 & Total & 7 & 8 & 9 & 10 & 11 & 12 & Total & \\
\hline 1 & 25 & 25 & 25 & 25 & 25 & 25 & 150 & 25 & 25 & 25 & 25 & 25 & 25 & 150 & - \\
\hline 2 & 25 & 0 & 25 & 0 & 25 & 0 & 75 & 25 & 25 & 0 & 25 & 25 & 0 & 100 & - \\
\hline 3 & 0 & 25 & 25 & 25 & 0 & 25 & 100 & 25 & 25 & 25 & 0 & 25 & 25 & 125 & - \\
\hline 4 & 0 & 0 & 25 & 0 & 0 & 0 & 25 & 25 & 0 & 25 & 25 & 25 & 0 & 100 & - \\
\hline 5 & 0 & 0 & 25 & 0 & 0 & 0 & 25 & 25 & 0 & 25 & 0 & 25 & 0 & 75 & - \\
\hline \multirow[t]{3}{*}{6} & 0 & 0 & 0 & 0 & 0 & 0 & 0 & 0 & 0 & 0 & 0 & 0 & 0 & 0 & - \\
\hline & \multicolumn{7}{|c|}{ Between Cuttings 2 and 3} & \multicolumn{7}{|c|}{ Between Cuttings 3 and 4} & \\
\hline & 13 & 14 & 15 & 16 & 17 & 18 & Total & 19 & 20 & 21 & 22 & 23 & 24 & Total & \\
\hline 1 & 25 & 25 & 25 & 25 & 25 & 25 & 150 & 25 & 25 & 25 & 25 & 25 & 25 & 150 & 600 \\
\hline 2 & 25 & 0 & 25 & 0 & 25 & 25 & 100 & 25 & 0 & 25 & 25 & 0 & 25 & 100 & 375 \\
\hline 3 & 0 & 0 & 0 & 0 & 0 & 0 & 0 & 25 & 25 & 25 & 25 & 25 & 25 & 150 & 375 \\
\hline 4 & 0 & 0 & 0 & 0 & 0 & 0 & 0 & 0 & 25 & 0 & 25 & 0 & 25 & 75 & 200 \\
\hline 5 & 0 & 25 & 0 & 25 & 0 & 0 & 50 & 25 & 0 & 25 & 0 & 0 & 0 & 50 & 200 \\
\hline 6 & 0 & 0 & 0 & 0 & 0 & 0 & 0 & 0 & 0 & 0 & 0 & 0 & 0 & 0 & 0 \\
\hline
\end{tabular}

due to the depletion of the aquifer. Irrigation events for treatments 2 and 5 were distributed over the time periods before each cutting to simulate wells with even lower capacity. Most of the water not applied to treatments 3 and 4 between the second and third cuttings was applied before the first and fourth cuttings. This template was devised from the best judgment of the research collaborators considering best management practices for irrigation management of alfalfa.

Actual irrigation applications deviated slightly from the template (tables 2 and 3), primarily because of the soil water content and precipitation for the particular year (fig. 1). The total irrigation for each treatment was the same for 20082011, except for treatment 1 in 2010 (table 3). The last irrigation of the year was not applied to that treatment due to mechanical problems with the irrigation system. In 2007, the total irrigation in treatments 2 and 3 was $457 \mathrm{~mm}$ because some water rights in Kansas limit irrigation to $457 \mathrm{~mm}$ per year. After 2007, the interval between irrigation amounts among treatments was made more uniform by applying $380 \mathrm{~mm}$, rather than $457 \mathrm{~mm}$, to treatments 2 and 3. Irrigation amounts before the first cutting were withheld when soil water content in treatment 1 was sufficient for production and was used later in the season, most notably in 2007. Water applications favored higher potential yields for cuttings 1 and 2. All of these management adjustments were intended to make the best use of irrigation to obtain the best yield response rather than to follow the strict schedule of the template.

\section{Agronomic Management}

Alfalfa was seeded on 17 August 2006, with a no-till grain drill in rows $190 \mathrm{~mm}$ apart into corn residue from the 2005 corn crop. A glyphosate-resistant alfalfa variety (Liberator from Northrup King) was used for the study. This offered the possibility of reducing or eliminating weeds for higher yield. A prophylactic application of glyphosate [N(phosphonomethyl) glycine] was made one month after alfalfa seedling emergence to ensure the area was free of any winter annual weeds. No further winter annual weeds were noted until the third year of production. These were removed with an early spring application of glyphosate, followed by a pre-emergence application of simazine and pendimethalin

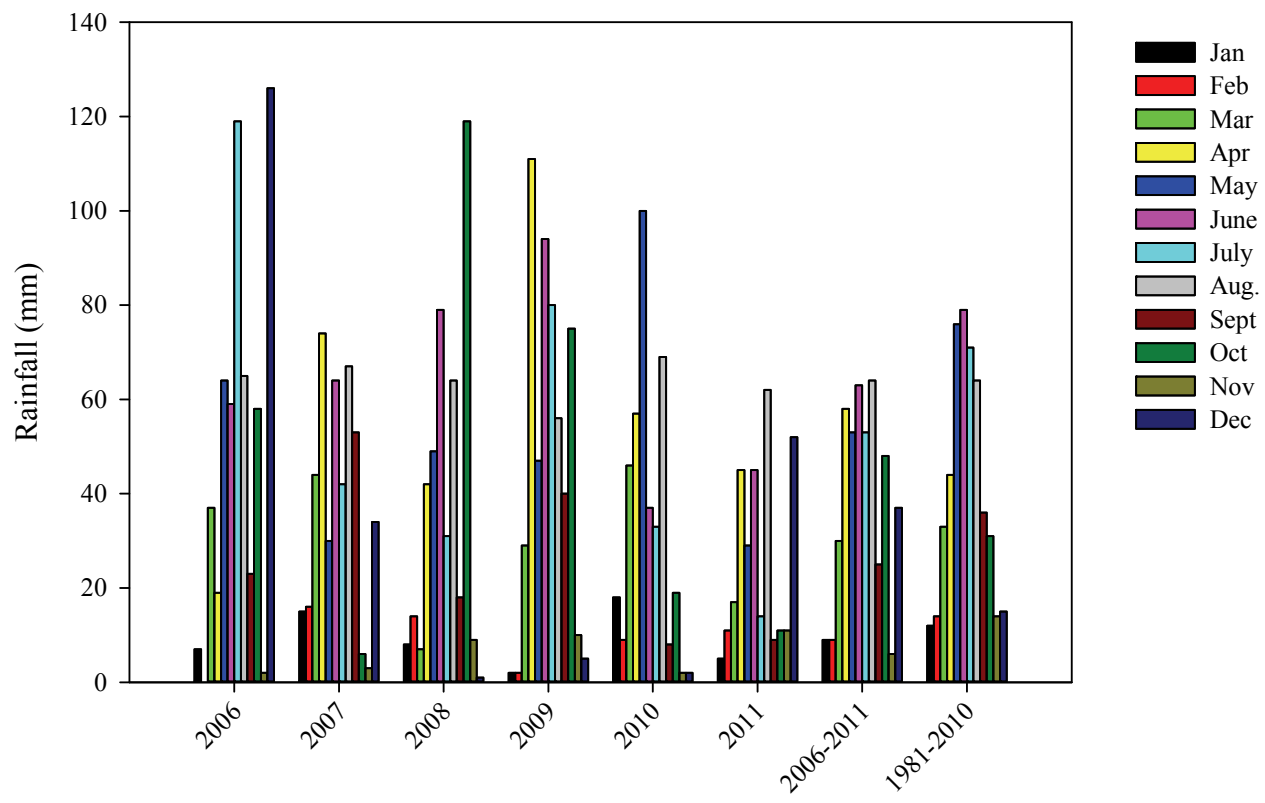

Figure 1. Monthly study period (2006-2011) precipitation and 30-year (1981-2010) mean monthly precipitation at Kansas State University SWREC near Garden City, Kansas. 
Table 3. Actual irrigation applied by irrigation treatment for each year, before and between cuttings, and total for the year at Kansas State University SWREC near Garden City, Kansas, from 2007 through 2011 (all values are in mm).

\begin{tabular}{|c|c|c|c|c|c|c|c|c|c|c|c|c|c|c|c|}
\hline \multirow{2}{*}{$\begin{array}{l}\text { Irrigation } \\
\text { Treatment }\end{array}$} & \multicolumn{5}{|c|}{ Before Cutting 1} & \multicolumn{5}{|c|}{ Between Cuttings 1 and 2} & \multicolumn{5}{|c|}{ Between Cuttings 2 and 3} \\
\hline & 2007 & 2008 & 2009 & 2010 & 2011 & 2007 & 2008 & 2009 & 2010 & 2011 & 2007 & 2008 & 2009 & 2010 & 2011 \\
\hline 1 & 0 & 76 & 102 & 76 & 152 & 152 & 152 & 102 & 178 & 152 & 152 & 152 & 152 & 152 & 178 \\
\hline 2 & 0 & 51 & 51 & 51 & 76 & 102 & 102 & 76 & 102 & 102 & 102 & 102 & 102 & 102 & 102 \\
\hline 3 & 0 & 51 & 76 & 51 & 102 & 127 & 127 & 76 & 152 & 127 & 0 & 0 & 0 & 0 & 0 \\
\hline 4 & 0 & 0 & 25 & 25 & 25 & 102 & 102 & 76 & 102 & 102 & 0 & 0 & 0 & 0 & 0 \\
\hline 5 & 0 & 0 & 25 & 25 & 25 & 76 & 76 & 51 & 76 & 76 & 51 & 51 & 51 & 51 & 76 \\
\hline \multirow[t]{3}{*}{6} & 0 & 0 & 0 & 0 & 0 & 0 & 0 & 0 & 0 & 0 & 0 & 0 & 0 & 0 & 0 \\
\hline & \multicolumn{5}{|c|}{ Between Cuttings 3 and 4} & \multicolumn{5}{|c|}{ Between Cuttings 4 and $5^{[a]}$} & \multicolumn{5}{|c|}{ Total } \\
\hline & 2007 & 2008 & 2009 & 2010 & 2011 & 2007 & 2008 & 2009 & 2010 & 2011 & 2007 & 2008 & 2009 & 2010 & 2011 \\
\hline 1 & 152 & 152 & 203 & 152 & 127 & 152 & 76 & 25 & 51 & 0 & 610 & 610 & 610 & $584^{[b]}$ & 610 \\
\hline 2 & 76 & 102 & 127 & 102 & 102 & 178 & 25 & 25 & 25 & 0 & 457 & 381 & 381 & 381 & 381 \\
\hline 3 & 152 & 152 & 203 & 152 & 152 & 178 & 51 & 0 & 25 & 0 & 457 & 381 & 356 & 381 & 381 \\
\hline 4 & 76 & 76 & 102 & 76 & 76 & 25 & 25 & 0 & 0 & 0 & 203 & 203 & 203 & 203 & 203 \\
\hline 5 & 51 & 51 & 766 & 51 & 25 & 25 & 25 & 0 & 0 & 0 & 203 & 203 & 203 & 203 & 203 \\
\hline 6 & 0 & 0 & 0 & 0 & 0 & 0 & 0 & 0 & 0 & 0 & 0 & 0 & 0 & 0 & 0 \\
\hline
\end{tabular}

[a] There were five cuttings in 2007 and 2008 and four cuttings in the other years.

[b] The last irrigation not applied due to mechanical failure of irrigation system.

to prevent winter and summer annual weeds. During the first four years, non-economically yield-damaging populations of Palmer amaranth (Amaranthus palmeri) were noted after the second or third cuttings. To remove this as a factor among treatments, these weeds were removed with an application of glyphosate. Although aggressive weed control tactics were implemented, control of Palmer amaranth and kochia (Kochia scoparia L.) began to fail by the fourth year as stands in the lower irrigation treatments began to thin. By the last cutting of the fifth year, glyphosate-resistant kochia had emerged as the dominant weed species in the lowest irrigation treatments. No summer annual grass species were present during this experiment.

Alfalfa was harvested in the plots when the majority of the plants reached $10 \%$ bloom and when more than $50 \%$ of crown buds had regrowth of $13 \mathrm{~mm}$. Occasionally there was no regrowth in the dryland treatment, and that treatment had fewer harvests than full irrigation. Harvest was conducted with a sickle-bar swather cutting a $4.27 \mathrm{~m}$ wide swath, $7 \mathrm{~cm}$ high, from the center of the plot and windrowing it in one operation. Yield samples $\left(3.9 \mathrm{~m}^{2}\right)$ were obtained manually by collecting a $0.91 \mathrm{~m}$ length of the full-width windrow and weighing the sample. Homogenized subsamples of the yield samples were oven-dried at $60^{\circ} \mathrm{C}$ for at least $48 \mathrm{~h}$ or until dry to determine percentage dry matter and forage nutritive value. Stands were counted during the dormant season (late fall and early spring) for each plot by averaging plant counts from four $0.25 \mathrm{~m}^{2}$ quadrats. Yield and stand were reported previously (Klocke et al., 2013).

\section{Forage Nutritive VALUE}

Forage nutritive value was determined from herbage sampled on harvest dates in 2008-2011. Forage nutritive value was not determined the first year (2007) because soil water content and yields were high in the low irrigation treatments due to higher amounts of irrigation plus precipitation in previous years. The samples were ground to pass a $1 \mathrm{~mm}$ Wiley mill screen. Crude protein was analyzed by the Kjeldahl method and was calculated by multiplying the Kjeldahl nitrogen concentration by 6.25 , and acid detergent fiber (ADF) and neutral detergent fiber (NDF) were analyzed by the method of Goering and Van Soest (1970). Total digestible nutrients (TDN) and relative feed value (RFV) were estimated according to equations 1 and 2:

$$
\begin{gathered}
\mathrm{TDN}=4.898+([1.044-(0.0119 \times \% \mathrm{ADF})] \times 89.796) \\
\mathrm{RFV}=\mathrm{DMI} \times \mathrm{DDM} \times 0.775
\end{gathered}
$$

where DMI is dry matter intake (DMI $=120 / \%$ NDF dry matter basis), and DDM is digestible dry matter (DDM = 88.9 - [0.779 ×\%ADF dry matter basis]) (Lofgreen, 1953; Rohweder et al., 1978). Crude protein is a measurement of protein content (with the assumption that proteins contain $16 \%$ nitrogen on average), NDF is a measurement of plant cell wall components (cellulose, hemicellulose, lignin, silica, insoluble CP, and ash), ADF is a measurement of NDF minus hemicellulose, TDN is an estimate of feed energy value, and RFV is an index used to compare the quality of forages relative to the feed value of full bloom alfalfa (Collins and Fritz, 2003). Seasonal forage nutritive values were calculated by the mean values across cuttings, weighted on forage dry matter yield at each cutting, and analyzed by irrigation treatment and year with an analysis of variance method using the Proc Mixed procedure of SAS (ver. 9.1 TS1M3, SAS Institute, Inc., Cary, N.C.). Block was considered a random effect with year as a fixed effect because alfalfa has a limited stand life and age of stand can affect results. Treatment means were separated using Fisher's protected LSD at $p \leq 0.05$. Similarly, forage nutritive values were analyzed by cutting averaged across years with an analysis of variance method using the Proc Mixed procedure of SAS, and treatment means were separated using Fisher's protected LSD at $p \leq 0.05$. The presence or absence of weeds was determined from the whole plot at each harvest by visual determination and was used as a covariate in the model to test for weed effects on forage nutritive value at $\mathrm{p} \leq 0.05$.

\section{RESULTS AND DISCUSSION \\ PreciptTation, SOIL Water, AND ET}

With the exception of the 2007-2008 and 2010-2011 for which dormant season rainfall was below normal, in all other years of the study dormant season rainfall was equal to or above normal (1981-2010), as reported by Klocke et al. 
(2013). On average, growing season rainfall was $61 \mathrm{~mm}$ below normal during the study period. Given the relatively flat topography of the study area and the semi-arid climate, all rainfall received was assumed effective in water balance calculations.

Soil water profiles during the spring and fall are shown in figure 2 (for full irrigation, dryland, and average of all six treatments as examples to depict changes in soil water during the study period). The soil water profiles were affected by dormant season rainfall, growing season rainfall, and irrigation amount. Timing of irrigation did not substantially affect soil water; the effect of irrigation amount was greater than the effect of timing. Figure 2 indicates that alfalfa extracted soil water down to $2.4 \mathrm{~m}$ or even deeper during the 2007 growing season, as reported by Klocke et al. (2013). This was because the above-normal rainfall in 2006 helped to recharge the soil profile. However, during the other years of the study, very little soil water was extracted at depths greater than $2.0 \mathrm{~m}$ because water was not available (volumetric soil water content had approached permanent wilting point). With the exception of 2011 (showing negligible changes in soil water profiles between spring and fall), for all other years the soil water in the top $2.0 \mathrm{~m}$ of the profile contributed in varying degrees to $\mathrm{ET}_{c}$, as shown by the soil water profile in figure 2.

Stored soil water contributed to $\mathrm{ET}_{c}$ for all treatments in
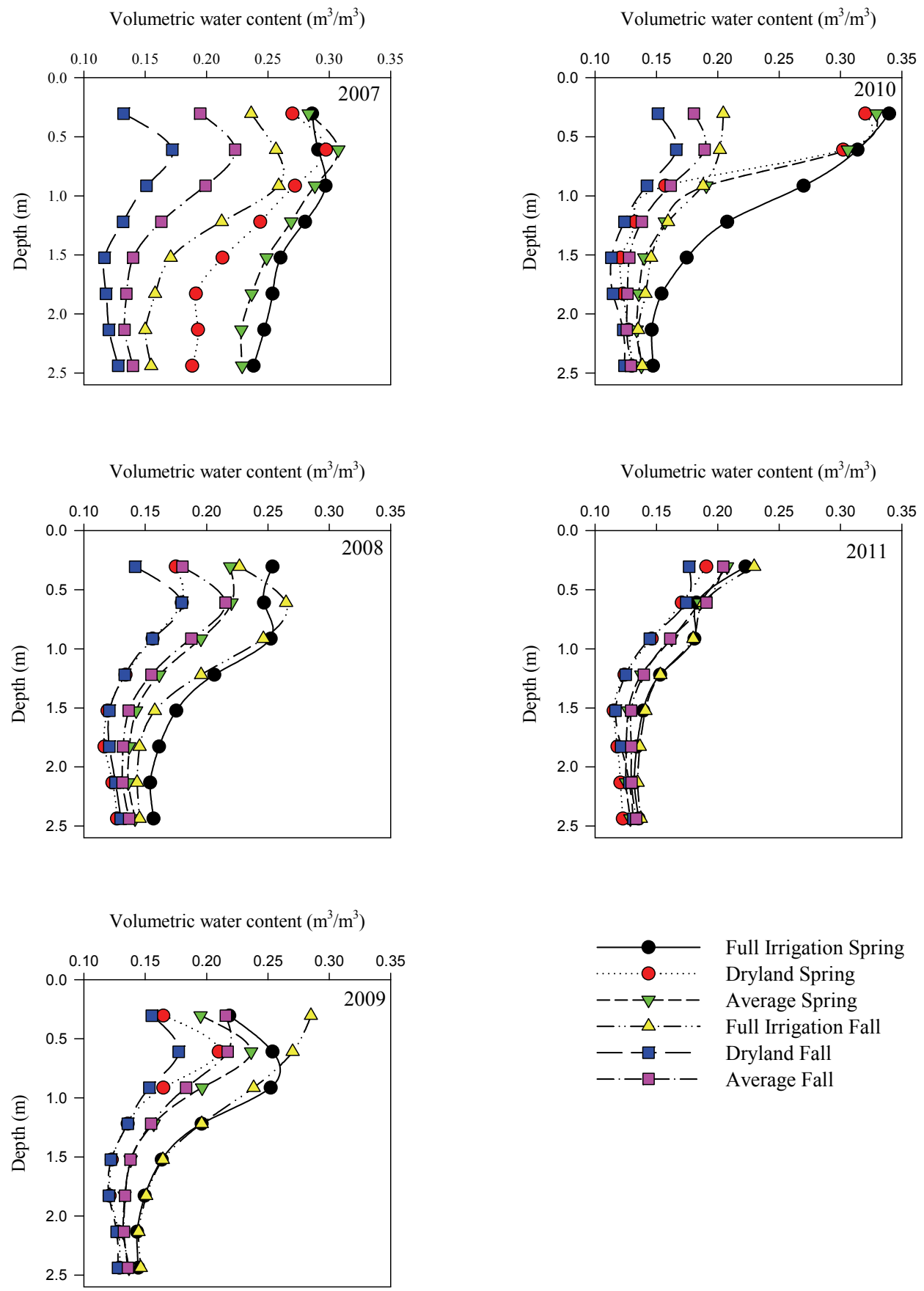

Figure 2. Soil water profiles for full irrigation, dryland, and average of all six treatments during the spring and fall from 2007 to 2011. 
most years, as shown in table 4 . With the exception of treatments 1, 2, and 3 during the 2009 growing season, in which there was soil water recharge, for all other years stored soil water contributed to $\mathrm{ET}_{c}$, as estimated by the difference between measured $\mathrm{ET}_{c}$ and the sum of growing season (April to September) precipitation and irrigation. The soil water contribution to $\mathrm{ET}_{c}$ was greatest during the 2007 and 2010 growing seasons due to above-normal annual rainfall in 2006 and 2009 that resulted in large soil water storage during the dormant season. Klocke et al. (2013) reported that the yield response to $\mathrm{ET}_{c}$ was curvilinear for 2007, and additional water beyond that applied to treatment 1 would not have produced substantial increases in yield. Additional irrigation to treatment 1 in 2008, 2010, and 2011 could have produced more yields given the quadratic production functions for these years, as previously reported by Klocke et al. (2013). There was little contribution of soil water to $\mathrm{ET}_{c}$ during the drought of 2011 because available soil water was depleted.

\section{Crude Protein (CP)}

Crude protein concentration in alfalfa ranged from 195 to $265 \mathrm{~g} \mathrm{~kg}^{-1}$ under six irrigation treatments during 2008-2011 (table 5). Crude protein tended to decrease as irrigation increased. Irrigation treatment 6 had higher CP concentration than other irrigation treatments in 2008, which indicates that rainfed treatments may have an advantage in having higher CP concentrations than irrigated treatments in some years. Previous research showed that drought increased the CP concentration (Vough and Marten, 1971; Peterson et al., 1992).
Table 5. Comparison of seasonal crude protein concentrations calculated from weighted mean values from each cutting using forage dry matter yield at Kansas State University SWREC near Garden City, Kansas.

\begin{tabular}{|c|c|c|c|c|c|}
\hline \multirow{2}{*}{$\begin{array}{c}\text { Irrigation } \\
\text { Treatment }^{[\mathrm{a}]}\end{array}$} & \multirow{2}{*}{$\begin{array}{c}\text { Total } \\
\text { Irrigation } \\
(\mathrm{mm})\end{array}$} & \multicolumn{4}{|c|}{ Crude Protein $\left(\mathrm{g} \mathrm{kg}^{-1}\right)^{[\mathrm{b}]}$} \\
\hline & & 2008 & 2009 & 2010 & 2011 \\
\hline 1 & 610 & $224 \mathrm{Ae}$ & $217 \mathrm{ABc}$ & $199 \mathrm{Cc}$ & $207 \mathrm{BCc}$ \\
\hline 2 & 380 & 233 ABde & $227 \mathrm{Babc}$ & $209 \mathrm{Cbc}$ & $243 \mathrm{Aa}$ \\
\hline 3 & 380 & 238 Acd & $221 \mathrm{Cbc}$ & $206 \mathrm{Dbc}$ & $223 \mathrm{BCb}$ \\
\hline 4 & 200 & $249 \mathrm{Abc}$ & $237 \mathrm{Ba}$ & $212 \mathrm{Cab}$ & $221 \mathrm{Cb}$ \\
\hline 5 & 200 & $248 \mathrm{Abc}$ & $230 \mathrm{BCab}$ & $221 \mathrm{Ca}$ & $242 \mathrm{ABa}$ \\
\hline 6 & 0 & $265 \mathrm{Aa}$ & $231 \mathrm{Bab}$ & $212 \mathrm{Cab}$ & $195 \mathrm{Dd}$ \\
\hline
\end{tabular}

a] In treatments 2 and 5, irrigation was applied after green-up and between all cuttings. In treatments 3 and 4, no irrigation was applied between cuttings 2 and 3.

[b] Different uppercase letters in each row indicate that year is significant within the same irrigation treatment at $\mathrm{p} \leq 0.05$. Different lowercase letters in each column indicate that irrigation treatment is significant within the same year at $\mathrm{p} \leq 0.05$.

Increased overall forage nutritive value resulted from an increase in the leaf:stem ratio (Vough and Marten, 1971; Carter and Sheaffer, 1983; Halim et al., 1989; Peterson et al., 1992) and a decrease in the rate of plant maturation (Halim et al., 1989). Irrigation amount affected CP concentration similarly to drought in that CP tended to decrease as irrigation level increased. However, this did not occur in 2011 when treatment 6 (rainfed) had lower CP concentration, which was likely due in part to the stand becoming very thin and weeds becoming more prevalent. There was a tendency for weeds to reduce $\mathrm{CP}$ concentration (table 6). When comparing applying irrigation between all cuttings and applying

Table 4. Crop evapotranspiration, growing season rainfall (April to September), and irrigation during the study period (2007 to 2011$)$.

\begin{tabular}{|c|c|c|c|c|c|c|}
\hline Year & $\begin{array}{l}\text { Irrigation } \\
\text { Treatment }\end{array}$ & $\begin{array}{c}\text { Crop } \\
\text { Evapotranspiration } \\
\left(\mathrm{ET}_{c}, \mathrm{~mm}\right)\end{array}$ & $\begin{array}{c}\text { Precipitation During } \\
\text { Growing Season } \\
\text { (April to Sept.) } \\
\text { (mm) }\end{array}$ & $\begin{array}{l}\text { Irrigation } \\
(\mathrm{mm})\end{array}$ & $\begin{array}{l}\text { Sum of } \\
\text { Precipitation } \\
\text { and Irrigation } \\
(\mathrm{mm})\end{array}$ & $\begin{array}{c}\text { Difference between } \\
\mathrm{ET}_{c} \text { and Sum of } \\
\text { Precipitation } \\
\text { and Irrigation } \\
(\mathrm{mm})\end{array}$ \\
\hline \multirow{6}{*}{2007} & 1 & 1137 & 330 & 610 & 940 & -197 \\
\hline & 2 & 1042 & 330 & 457 & 787 & -255 \\
\hline & 3 & 1026 & 330 & 457 & 787 & -239 \\
\hline & 4 & 833 & 330 & 203 & 533 & -300 \\
\hline & 5 & 830 & 330 & 203 & 533 & -297 \\
\hline & 6 & 602 & 330 & 0 & 330 & -272 \\
\hline \multirow{6}{*}{2008} & 1 & 914 & 283 & 610 & 893 & -21 \\
\hline & 2 & 701 & 283 & 381 & 664 & -37 \\
\hline & 3 & 699 & 283 & 381 & 664 & -35 \\
\hline & 4 & 500 & 283 & 203 & 486 & -14 \\
\hline & 5 & 500 & 283 & 203 & 486 & -14 \\
\hline & 6 & 287 & 283 & 0 & 283 & -4 \\
\hline \multirow{6}{*}{2009} & 1 & 956 & 428 & 610 & 1038 & 82 \\
\hline & 2 & 775 & 428 & 381 & 809 & 34 \\
\hline & 3 & 765 & 428 & 356 & 784 & 19 \\
\hline & 4 & 640 & 428 & 203 & 631 & -9 \\
\hline & 5 & 647 & 428 & 203 & 631 & -16 \\
\hline & 6 & 437 & 428 & 0 & 428 & -9 \\
\hline \multirow{6}{*}{2010} & 1 & 1023 & 304 & 584 & 888 & -135 \\
\hline & 2 & 796 & 304 & 381 & 685 & -111 \\
\hline & 3 & 777 & 304 & 381 & 685 & -92 \\
\hline & 4 & 632 & 304 & 203 & 507 & -125 \\
\hline & 5 & 636 & 304 & 203 & 507 & -129 \\
\hline & 6 & 438 & 304 & 0 & 304 & -134 \\
\hline \multirow{6}{*}{2011} & 1 & 828 & 204 & 610 & 814 & -14 \\
\hline & 2 & 599 & 204 & 381 & 585 & -14 \\
\hline & 3 & 599 & 204 & 381 & 585 & -14 \\
\hline & 4 & 418 & 204 & 203 & 407 & -11 \\
\hline & 5 & 426 & 204 & 203 & 407 & -19 \\
\hline & 6 & 222 & 204 & 0 & 204 & -18 \\
\hline
\end{tabular}


Table 6. Weed effects as a covariate on alfalfa nutritive value $(C P=$ crude protein, $\mathrm{ADF}=$ acid detergent fiber, $\mathrm{NDF}=$ neutral detergent fiber, TDN = total digestible nutrients, and $\mathrm{RFV}=$ relative feed value).

\begin{tabular}{ccccccc}
\hline & $N^{[\mathrm{a}]}$ & CP & ADF & NDF & TDN & RFV \\
\hline Weeds & 21 & 223 & 231 & 359 & 739 & 187 \\
No weeds & 327 & 228 & 270 & 370 & 697 & 176 \\
\hline Significance $^{[\mathrm{b}]}$ & - & NS & $* *$ & NS & $* *$ & NS
\end{tabular}

[a] $N=$ number of plots with or without weeds present at harvest.

[b] NS = not significantly different at $\mathrm{p} \leq 0.05$ level within same column. Asterisks $(* *)$ indicate significant difference at $\mathrm{p} \leq 0.01$

Table 7. Crude protein comparison averaged across years (2008-2011) by cutting and irrigation treatment at Kansas State University SWREC near Garden City, Kansas.

\begin{tabular}{cccccc}
\hline & Total & \multicolumn{4}{c}{ Crude Protein $\left(\mathrm{g} \mathrm{kg}^{-1}\right)^{[\mathrm{b}]}$} \\
\cline { 3 - 6 } Irrigation $_{\text {Treatment }^{\mathrm{a}]}}$ & $\begin{array}{c}\text { Irrigation } \\
(\mathrm{mm})\end{array}$ & $\begin{array}{c}\text { First } \\
\text { Cutting }\end{array}$ & $\begin{array}{c}\text { Second } \\
\text { Cutting }\end{array}$ & $\begin{array}{c}\text { Third } \\
\text { Cutting }\end{array}$ & $\begin{array}{c}\text { Fourth } \\
\text { Cutting }\end{array}$ \\
\hline 1 & 610 & $177 \mathrm{Aa}$ & $212 \mathrm{Ba}$ & $213 \mathrm{Ba}$ & $216 \mathrm{Ba}$ \\
2 & 380 & $195 \mathrm{Ab}$ & $223 \mathrm{AaB}$ & $240 \mathrm{Cb}$ & $228 \mathrm{DCa}$ \\
3 & 380 & $195 \mathrm{Ab}$ & $219 \mathrm{Bab}$ & $233 \mathrm{Bb}$ & $219 \mathrm{Ba}$ \\
4 & 200 & $206 \mathrm{Ab}$ & $231 \mathrm{Bb}$ & $236 \mathrm{Bb}$ & $221 \mathrm{ABa}$ \\
5 & 200 & $206 \mathrm{Ab}$ & $236 \mathrm{BCb}$ & $245 \mathrm{Cb}$ & $225 \mathrm{Ba}$ \\
6 & 0 & $204 \mathrm{Ab}$ & $266 \mathrm{Cc}$ & ${ }_{-[\mathrm{c}]}$ & $234 \mathrm{Ba}$ \\
\hline
\end{tabular}

[a] In treatments 2 and 5, irrigation was applied after green-up and between all cuttings. In treatments 3 and 4, no irrigation was applied between cuttings 2 and 3 .

[b] Different uppercase letters in each row indicate that cutting is significant within the same irrigation treatment averaged across years at $\mathrm{p} \leq$ 0.05 . Different lowercase letters in each column indicate that irrigation treatment is significant within the same cutting averaged across years at $\mathrm{p} \leq 0.05$

[c] Alfalfa was not harvested at the third cutting due to dry conditions and no regrowth.

none between cuttings 2 and 3, no significant difference in $\mathrm{CP}$ concentration was found in the 200 and $380 \mathrm{~mm}$ irrigation treatments during the study except in 2011, when applying irrigation between all cuttings increased CP concentration. These results suggest that irrigation can be withheld in most years between the second and third cuttings without affecting $\mathrm{CP}$ concentration.

Within an irrigation treatment, crude protein concentration tended to be lower from the first cutting compared to the other cuttings when averaged across years (table 7). This result concurs with a previous report (Peterson et al., 1992) in which first and second cuttings of alfalfa had average $\mathrm{CP}$ concentration of 194 and $233 \mathrm{~g} \mathrm{~kg}^{-1} \mathrm{DM}$, respectively, in Minnesota. In the second cutting, irrigation treatment 6 (rainfed) had the highest CP concentration of any irrigation treatment. At the first and third cuttings, irrigation treatment $1(610 \mathrm{~mm})$ had lower CP concentration than the other irrigation treatments. Timing did not affect the $\mathrm{CP}$ concentration under the same amount of irrigation (i.e., between treatments 2 and 3 or between treatments 4 and 5).

\section{ACID Detergent Fiber (ADF)}

The ADF concentration tended to decrease as irrigation decreased (table 8). Averaged across years 2008 through 2011, $610 \mathrm{~mm}$ of irrigation had higher ADF concentration than the other irrigation treatments, and $200 \mathrm{~mm}$ of irrigation and rainfed production had less ADF concentration than $380 \mathrm{~mm}$ of irrigation (table 8). The lower the ADF concentration, the better the forage digestibility; thus, lowering irrigation amounts might improve forage digestibility by reducing ADF concentration. With the exception of applying
Table 8. Comparison of seasonal acid detergent fiber concentrations calculated from weighted mean values from each cutting using forage dry matter yield at Kansas State University SWREC near Garden City, Kansas.

\begin{tabular}{cccccc}
\hline & \multirow{2}{*}{$\begin{array}{c}\text { Total } \\
\text { Irrigation }\end{array}$} & \multicolumn{4}{c}{ Acid Detergent } \\
Irrigation & & \multicolumn{4}{c}{ Fiber $\left(\mathrm{g} \mathrm{kg}^{-1}\right)^{[\mathrm{b}]}$} \\
\cline { 3 - 6 } Treatment $^{[\mathrm{a}]}$ & $(\mathrm{mm})$ & 2008 & 2009 & 2010 & 2011 \\
\hline 1 & 610 & $319 \mathrm{Aa}$ & $335 \mathrm{Aa}$ & $332 \mathrm{Aa}$ & $277 \mathrm{Ba}$ \\
2 & 380 & $292 \mathrm{ABb}$ & $303 \mathrm{Acd}$ & $281 \mathrm{Bb}$ & $223 \mathrm{Cbc}$ \\
3 & 380 & $287 \mathrm{Ab}$ & $304 \mathrm{Ab}$ & $293 \mathrm{Ab}$ & $231 \mathrm{Bb}$ \\
4 & 200 & $266 \mathrm{Ac}$ & $275 \mathrm{Ad}$ & $262 \mathrm{Acd}$ & $236 \mathrm{Bb}$ \\
5 & 200 & $263 \mathrm{Bc}$ & $286 \mathrm{Acd}$ & $249 \mathrm{Bd}$ & $211 \mathrm{Cc}$ \\
6 & 0 & $227 \mathrm{Bd}$ & $273 \mathrm{Ad}$ & $263 \mathrm{Acd}$ & $224 \mathrm{Bbc}$ \\
\hline
\end{tabular}

[a] In treatments 2 and 5, irrigation was applied after green-up and between all cuttings. In treatments 3 and 4, no irrigation was applied between cuttings 2 and 3.

[b] Different uppercase letters in each row indicate that year is significant within the same irrigation treatment at $\mathrm{p} \leq 0.05$. Different lowercase letters in each column indicate that irrigation treatment is significant within the same year at $\mathrm{p} \leq 0.05$.

$200 \mathrm{~mm}$ in 2011, no difference was found between treatments 2 and 3 or between treatments 4 and 5, indicating that irrigating at mid-summer does not appear helpful in reducing the ADF concentration in alfalfa under both 380 and $200 \mathrm{~mm}$ of irrigation. In 2011, ADF was less when irrigation was applied evenly across all cuttings at the $200 \mathrm{~mm}$ amount, which may have been due in part to the presence of weeds. Unlike $\mathrm{CP}$ and NDF (tables 6 and 10), ADF was significantly reduced by the presence of weeds in this study. The weeds were harvested at a vegetative stage along with the alfalfa, which may explain why weeds did not have a negative impact on ADF concentration. The lower ADF concentration associated with less water is consistent with other research that found drought tended to increase the leaf:stem ratio, resulting in lower ADF concentration in alfalfa (Vough and Marten, 1971; Peterson et al., 1992). Averaged across legumes such as alfalfa, birdsfoot trefoil, cicer milkvetch, and red clover, drought-stricken legumes decreased their ADF concentration by $38 \%$ compared with the non-drought control in Minnesota (Peterson et al., 1992).

The ADF concentrations from the first and second cuttings were higher than the third and fourth cuttings when averaged across irrigation treatments (table 9). Applying $610 \mathrm{~mm}$ of irrigation (the highest irrigation amount) produced higher ADF concentrations than all other irrigation treatments at all cuttings. Withholding irrigation mid-summer and applying part of this saved water toward the fourth cutting (i.e., between treatments 2 and 3 or between treatments 4 and 5), tended to increase the ADF concentration of treatments 3 and 4 at the fourth cutting. This trend was consistent with irrigation amount, where applying more irrigation tended to increase ADF concentration (table 8).

\section{Neutral Detergent Fiber (NDF)}

The NDF concentrations of alfalfa in 2011, the driest year, were lower than in other years for each irrigation treatment except treatment 6 (table 10). Precipitation in 2010 and 2011 was less than in 2008 and 2009 (fig. 1), and lower precipitation tended to reduce NDF concentration. Peterson et al. (1992) reported that drought-affected alfalfa and red clover had 25\% less NDF concentration than their well-watered controls, whereas birdsfoot trefoil and cicer milkvetch had 
Table 9. Acid detergent fiber comparison averaged across years (20082011) by cutting and irrigation treatment at Kansas State University SWREC near Garden City, Kansas.

\begin{tabular}{cccccc}
\hline & Total & \multicolumn{4}{c}{ Acid Detergent Fiber $\left(\mathrm{g} \mathrm{kg}^{-1}\right)^{[\mathrm{b}]}$} \\
\cline { 3 - 6 } Irrigation $_{\text {Treatment }^{\mathrm{a}]}}$ & $\begin{array}{c}\text { Irrigation } \\
(\mathrm{mm})\end{array}$ & $\begin{array}{c}\text { First } \\
\text { Cutting }\end{array}$ & $\begin{array}{c}\text { Second } \\
\text { Cutting }\end{array}$ & $\begin{array}{c}\text { Third } \\
\text { Cutting }\end{array}$ & $\begin{array}{c}\text { Fourth } \\
\text { Cutting }\end{array}$ \\
\hline 1 & 610 & $324 \mathrm{Aa}$ & $312 \mathrm{Aa}$ & $329 \mathrm{Aa}$ & $284 \mathrm{Ba}$ \\
2 & 380 & $290 \mathrm{Ab}$ & $287 \mathrm{Ab}$ & $254 \mathrm{Bb}$ & $249 \mathrm{Bbc}$ \\
3 & 380 & $292 \mathrm{Ab}$ & $286 \mathrm{Ab}$ & $235 \mathrm{Bbc}$ & $275 \mathrm{Aa}$ \\
4 & 200 & $256 \mathrm{Ac}$ & $268 \mathrm{Abc}$ & $228 \mathrm{Bc}$ & $248 \mathrm{Abc}$ \\
5 & 200 & $261 \mathrm{Ac}$ & $255 \mathrm{Ac}$ & $223 \mathrm{Bc}$ & $239 \mathrm{ABc}$ \\
6 & 0 & $259 \mathrm{Ac}$ & $243 \mathrm{Ac}$ & [c] $^{-c}$ & $221 \mathrm{Bc}$ \\
\hline
\end{tabular}

In treatments 2 and 5, irrigation was applied after green-up and between all cuttings. In treatments 3 and 4, no irrigation was applied between cuttings 2 and 3 .

[b] Different uppercase letters in each row indicate that cutting is significant within the same irrigation treatment averaged across years at $p \leq$ 0.05. Different lowercase letters in each column indicate that irrigation treatment is significant within the same cutting averaged across years at $\mathrm{p} \leq 0.05$

[c] Alfalfa was not harvested at the third cutting due to dry conditions and no regrowth.

Table 10. Comparison of seasonal neutral detergent fiber concentrations calculated from weighted mean values from each cutting using forage dry matter yield at Kansas State University SWREC near Garden City, Kansas.

\begin{tabular}{cccccc}
\hline & \multirow{2}{*}{$\begin{array}{c}\text { Total } \\
\text { Irrigation }\end{array}$} & \multicolumn{4}{c}{ Neutral Detergent Fiber $\left(\mathrm{g} \mathrm{kg}^{-1}\right)^{[\mathrm{b}]}$} \\
\cline { 3 - 6 } Ireatment $^{[\mathrm{a}]}$ & $(\mathrm{mm})$ & 2008 & 2009 & 2010 & 2011 \\
\hline 1 & 610 & $425 \mathrm{Aa}$ & $440 \mathrm{Aa}$ & $439 \mathrm{Aa}$ & $383 \mathrm{Ba}$ \\
2 & 380 & $389 \mathrm{Ab}$ & $403 \mathrm{Abc}$ & $385 \mathrm{Ac}$ & $318 \mathrm{Bc}$ \\
3 & 380 & $392 \mathrm{Ab}$ & $407 \mathrm{Ab}$ & $412 \mathrm{Ab}$ & $324 \mathrm{Bbc}$ \\
4 & 200 & $362 \mathrm{ABc}$ & $373 \mathrm{Ac}$ & $380 \mathrm{Acd}$ & $345 \mathrm{Bb}$ \\
5 & 200 & $363 \mathrm{ABc}$ & $384 \mathrm{Abc}$ & $358 \mathrm{Bd}$ & $315 \mathrm{Cc}$ \\
6 & 0 & $319 \mathrm{Bd}$ & $375 \mathrm{Ac}$ & $388 \mathrm{Ac}$ & $399 \mathrm{Aa}$
\end{tabular}

[a] In treatments 2 and 5, irrigation was applied after green-up and between all cuttings. In treatments 3 and 4, no irrigation was applied between cuttings 2 and 3 .

[b] Different uppercase letters in each row indicate that year is significant within the same irrigation treatment at $\mathrm{p} \leq 0.05$. Different lowercase letters in each column indicate that irrigation treatment is significant within the same year at $\mathrm{p} \leq 0.05$.

$35 \%$ less NDF concentration. As NDF concentration increases, feed intake decreases. Similar to ADF concentration, NDF concentration tended to decrease as irrigation decreased. The highest irrigation amount $(610 \mathrm{~mm})$ in 2008 , 2009, and 2010 produced significantly higher NDF concentrations than the other irrigation treatments. Applying irrigation between all cuttings or withholding irrigation between cuttings 2 and 3 (i.e., treatments 2 and 3 or treatments 4 and 5) did not affect NDF concentrations in 2008 or 2009. However, NDF concentration was less when irrigation of $380 \mathrm{~mm}$ was applied between cuttings in 2010 and $200 \mathrm{~mm}$ was applied between cuttings in 2011. This indicates that irrigating alfalfa after green-up and between all cuttings tended to lower NDF concentration compared to not irrigating in midsummer in 2010 and 2011. NDF concentration was not affected by weeds when averaged across irrigation treatments and cuttings (table 6).

With the exception of rainfed production, NDF concentration tended to be lower at the third and fourth cuttings compared to the first and second cuttings when irrigation was applied to every cutting (treatments 2 and 5) throughout the growing season. The NDF concentration at the highest
Table 11. Neutral detergent fiber comparison averaged across years (2008-2011) by cutting and irrigation treatment at Kansas State University SWREC near Garden City, Kansas.

\begin{tabular}{cccccc}
\hline & Total & \multicolumn{4}{c}{ Neutral Detergent Fiber $\left(\mathrm{g} \mathrm{kg}^{-1}\right)^{[\mathrm{b}]}$} \\
\cline { 3 - 6 } Irrigation $_{\text {Treatment }}{ }^{[\mathrm{a}]}$ & $\begin{array}{c}\text { Irrigation } \\
(\mathrm{mm})\end{array}$ & First & Second & Third & Fourth \\
\hline 1 & 610 & $444 \mathrm{Aa}$ & $418 \mathrm{Aa}$ & $426 \mathrm{Aa}$ & $382 \mathrm{Ba}$ \\
2 & 380 & $400 \mathrm{Ab}$ & $381 \mathrm{Ab}$ & $340 \mathrm{Bb}$ & $343 \mathrm{Bbc}$ \\
3 & 380 & $405 \mathrm{Ab}$ & $391 \mathrm{Ab}$ & $320 \mathrm{Bb}$ & $375 \mathrm{Aab}$ \\
4 & 200 & $359 \mathrm{Ac}$ & $365 \mathrm{Abc}$ & $309 \mathrm{Bb}$ & $364 \mathrm{Aab}$ \\
5 & 200 & $375 \mathrm{Ac}$ & $353 \mathrm{Acd}$ & $310 \mathrm{Bb}$ & $323 \mathrm{Bc}$ \\
6 & 0 & $362 \mathrm{Ac}$ & $335 \mathrm{Ad}$ & [c] & $358 \mathrm{Aabc}$ \\
\hline
\end{tabular}

[a] In treatments 2 and 5, irrigation was applied after green-up and between all cuttings. In treatments 3 and 4, no irrigation was applied between cuttings 2 and 3.

[b] Different uppercase letters in each row indicate that cutting is significant within the same irrigation treatment averaged across years at $\mathrm{p} \leq$ 0.05 . Different lowercase letters in each column indicate that irrigation treatment is significant within the same cutting averaged across years at $\mathrm{p} \leq 0.05$.

[c] Alfalfa was not harvested at the third cutting due to dry conditions and no regrowth.

irrigation amount $(610 \mathrm{~mm})$ was higher than for other irrigation treatments at all cuttings (table 11). These results indicate that high amounts of irrigation increase NDF concentration similar to the trend for ADF concentration throughout the growing season. Applying irrigation between all cuttings or withholding between the second and third cuttings (i.e., between treatments 2 and 3 and between treatments 4 and 5) did not affect NDF concentration at cuttings 1 to 3, but applying irrigation between all cuttings lowered NDF concentration at the fourth cutting.

\section{Total Digestible NutRIENTS (TDN)}

Total digestible nutrients decreased as irrigation increased (table 12). Total digestible nutrients were significantly higher in 2011, a dry year, and significantly less in 2009, a wet year (tables 4 and 12). The impact of weather coincides with the results of TDN and irrigation amount. Total digestible nutrients are an estimate of forage energy, with higher levels having more energy. Lower precipitation might have resulted in higher TDN by increasing the leaf:stem ratio. This result would be consistent with other studies (Vough and Marten, 1971; Carter and Sheaffer, 1983; Peterson et al., 1992) in which forage nutritive value was typically higher during a dry year than a wet year. The effect of irrigation and precipitation on TDN was consistent with the trends for $\mathrm{CP}, \mathrm{ADF}$, and NDF measured in this study. TDN concentration was not affected by applying irrigation between all cuttings nor by not irrigating between the second and third cuttings, except for the $200 \mathrm{~mm}$ irrigation treatment in 2011, which was associated with more weeds present that year when irrigation was applied between all cuttings. Total digestible nutrients were significantly increased by the presence of weeds (table 6), and this trend concurred with the effect of weeds on ADF content.

Similar to $\mathrm{CP}, \mathrm{ADF}$, and NDF, the TDN values were lower at the first and second cuttings than at the third and fourth cuttings (table 13). With the exception of the fourth cutting, TDN tended to increase as irrigation level decreased. Applying irrigation between all cuttings or withholding irrigation between the second and third cuttings did not affect TDN, with the exception of $380 \mathrm{~mm}$ at the fourth cutting, 
Table 12. Comparison of seasonal total digestible nutrients calculated from weighted mean values from each cutting using forage dry matter yield at Kansas State University SWREC near Garden City, Kansas. Total

\begin{tabular}{cccccc} 
& Trrigation & Irrigation & \multicolumn{4}{c}{ Total Digestible Nutrients $(\%)^{[\mathrm{b}]}$} \\
\cline { 3 - 6 } Treatment $^{[\mathrm{a}]}$ & $(\mathrm{mm})$ & 2008 & 2009 & 2010 & 2011 \\
\hline 1 & 610 & $64.6 \mathrm{Bd}$ & $62.9 \mathrm{Bc}$ & $63.1 \mathrm{Bc}$ & $69.1 \mathrm{Ac}$ \\
2 & 380 & $67.5 \mathrm{Bc}$ & $66.3 \mathrm{Bb}$ & $68.7 \mathrm{Bb}$ & $74.8 \mathrm{Ab}$ \\
3 & 380 & $68.0 \mathrm{Bc}$ & $66.2 \mathrm{Bb}$ & $67.5 \mathrm{Bb}$ & $74.0 \mathrm{Ab}$ \\
4 & 200 & $70.3 \mathrm{Bb}$ & $69.4 \mathrm{Ba}$ & $71.0 \mathrm{Ba}$ & $73.5 \mathrm{Ab}$ \\
5 & 200 & $70.6 \mathrm{Bb}$ & $68.1 \mathrm{Cab}$ & $72.0 \mathrm{Ba}$ & $76.2 \mathrm{Aa}$ \\
6 & 0 & $74.3 \mathrm{Aa}$ & $69.6 \mathrm{Ba}$ & $70.7 \mathrm{Ba}$ & $74.6 \mathrm{Aab}$ \\
\hline
\end{tabular}

a] In treatments 2 and 5, irrigation was applied after green-up and between all cuttings. In treatments 3 and 4, no irrigation was applied between cuttings 2 and 3 .

[b] Different uppercase letters in each row indicate that year is significant within the same irrigation treatment at $p \leq 0.05$. Different lowercase letters in each column indicate that irrigation treatment is significant within the same year at $\mathrm{p} \leq 0.05$.

Table 13. Total digestible nutrients comparison averaged across years (2008-2011) by cutting and irrigation treatment at Kansas State University SWREC near Garden City, Kansas.

\begin{tabular}{cccccc}
\hline & Total & \multicolumn{4}{c}{ Total Digestible Nutrients $(\%)^{[\mathrm{b}]}$} \\
\cline { 3 - 6 } Irrigation & $\begin{array}{c}\text { Irrigation } \\
\text { Treatment }\end{array}{ }^{[\mathrm{a}]}$ & First & Second & Third & Fourth \\
\hline 1 & 610 & $657 \mathrm{Bc}$ & $668 \mathrm{Bc}$ & $642 \mathrm{Bc}$ & $700 \mathrm{Ab}$ \\
2 & 380 & $692 \mathrm{Bb}$ & $695 \mathrm{Bb}$ & $724 \mathrm{Ab}$ & $738 \mathrm{Aa}$ \\
3 & 380 & $691 \mathrm{Bb}$ & $697 \mathrm{Bb}$ & $751 \mathrm{Aab}$ & $709 \mathrm{Bb}$ \\
4 & 200 & $730 \mathrm{Ba}$ & $717 \mathrm{Ba}$ & $759 \mathrm{Aa}$ & $736 \mathrm{ABa}$ \\
5 & 200 & $724 \mathrm{Ba}$ & $729 \mathrm{Ba}$ & $754 \mathrm{Aa}$ & $747 \mathrm{ABa}$ \\
6 & 0 & $726 \mathrm{Aa}$ & $743 \mathrm{Aa}$ & [c] & $744 \mathrm{Aa}$ \\
\hline
\end{tabular}

[a] In treatments 2 and 5, irrigation was applied after green-up and between all cuttings. In treatments 3 and 4, no irrigation was applied between cuttings 2 and 3 .

[b] Different uppercase letters in each row indicate that cutting is significant within the same irrigation treatment averaged across years at $p \leq$ 0.05. Different lowercase letters in each column indicate that irrigation treatment is significant within the same cutting averaged across years at $\mathrm{p} \leq 0.05$.

[c] Alfalfa was not harvested at the third cutting due to dry conditions and no regrowth.

which was higher when irrigation was applied to all cuttings. This trend in irrigation timing corresponded with the irrigation timing effect on ADF and NDF content.

\section{Relative Feed Value (RFV)}

Like TDN levels, 2011 had the highest RFV (193) compared with other years (table 14), and 2011 also had the lowest precipitation (fig. 1). This indicates that RFV might be

Table 14. Comparison of seasonal relative feed values calculated from weighted mean values from each cutting using forage dry matter yield at Kansas State University SWREC near Garden City, Kansas.

\begin{tabular}{|c|c|c|c|c|c|}
\hline \multirow{2}{*}{$\begin{array}{l}\text { Irrigation } \\
\text { Treatment }{ }^{[a]}\end{array}$} & \multirow{2}{*}{$\begin{array}{c}\text { Total } \\
\text { Irrigation } \\
\text { (mm) }\end{array}$} & \multicolumn{4}{|c|}{ Relative Feed Value ${ }^{[b]}$} \\
\hline & & 2008 & 2009 & 2010 & 2011 \\
\hline 1 & 610 & $143 \mathrm{Bd}$ & $134 \mathrm{Bc}$ & $135 \mathrm{Bd}$ & $166 \mathrm{Ac}$ \\
\hline 2 & 380 & $163 \mathrm{Bc}$ & $155 \mathrm{Bab}$ & $167 \mathrm{Bb}$ & $212 \mathrm{Aa}$ \\
\hline 3 & 380 & $163 \mathrm{Bc}$ & $152 \mathrm{Bb}$ & $152 \mathrm{Bc}$ & $205 \mathrm{Aab}$ \\
\hline 4 & 200 & $180 \mathrm{ABb}$ & $174 \mathrm{Ba}$ & $170 \mathrm{Bb}$ & $193 \mathrm{Ab}$ \\
\hline 5 & 200 & $181 \mathrm{Bb}$ & $167 \mathrm{Ca}$ & $188 \mathrm{Ba}$ & $215 \mathrm{Aa}$ \\
\hline 6 & 0 & $209 \mathrm{Aa}$ & $169 \mathrm{Ba}$ & $165 \mathrm{Bbc}$ & $168 \mathrm{Bc}$ \\
\hline
\end{tabular}

[a] In treatments 2 and 5, irrigation was applied after green-up and between all cuttings. In treatments 3 and 4, no irrigation was applied between cuttings 2 and 3 .

[b] Different uppercase letters in each row indicate that year is significant within the same irrigation treatment at $p \leq 0.05$. Different lowercase letters in each column indicate that irrigation treatment is significant within the same year at $\mathrm{p} \leq 0.05$. higher in dry years than in wet years. The exception was treatment 6 (rainfed), which had the highest RFV in 2008. Treatment 6 was always under drought stress compared to the irrigated treatments. The trend in RFV was correlated to irrigation amount, with the highest amount $(610 \mathrm{~mm})$ having a lower RFV value compared with the other irrigation treatments when averaged across years. Quality grades for alfalfa based on RFV are supreme ( $>185)$, premium (170 to 185), good (150 to 170$)$, fair (130 to 150$)$, and low $(<130)$. RFV varied by year across irrigation treatments, primarily due to differences in environmental conditions and likely due to slight variability in growth stage at harvest, although every attempt was made to harvest at similar growth stages across all treatments and years. The highest irrigation amount $(610 \mathrm{~mm})$ generally had an RFV grade of fair, while all other irrigation treatments had RFV grades of good to supreme. Applying irrigation between all cuttings increased RFV at the $380 \mathrm{~mm}$ level in 2010 and at the $200 \mathrm{~mm}$ level in 2010 and 2011 compared to no irrigation between the second and third cuttings (table 14).

Relative feed values were lower at the first and second cuttings than at the third and fourth cuttings (table 15), and this result was consistent with the ADF, NDF, and TDN values. Across all cuttings, RFV values tended to decrease as irrigation increased. Applying irrigation between all cuttings compared to not irrigating between the second and third cuttings only affected RFV at the 200 and $380 \mathrm{~mm}$ irrigation amounts at the fourth cutting, where applying irrigation between all cuttings improved RFV. This increase in RFV in 2011 was similar to the trend seen for TDN and ADF and was at least partly due to the increased presence of weeds in the final year of the study.

In 2014, supreme grade $\left(\$ 290 \mathrm{Mg}^{-1}\right)$ alfalfa sold for $10 \%$ more than premium grade $\left(\$ 260 \mathrm{Mg}^{-1}\right)$, and premium grade sold for $12 \%$ more than fair/good grade $\left(\$ 230 \mathrm{Mg}^{-1}\right)$ in southwest Kansas (USDA, 2014). Using a partial budget analysis for irrigated alfalfa, gross and net returns for all treatments were determined (table 16). The partial budget only accounted for variable costs that were affected by irrigation level, including baling, irrigation, and phosphorus (P) expenses, and excluded land rent, crop insurance, interest, and variable or fixed

Table 15. Relative feed value comparison averaged across years (20082011) by cutting and irrigation treatment at Kansas State University SWREC near Garden City, Kansas.

\begin{tabular}{cccccc}
\hline & Total & \multicolumn{4}{c}{ Relative Feed Value ${ }^{[\mathrm{b}]}$} \\
\cline { 3 - 6 } Irrigation $_{\text {Treatment }^{[\mathrm{a}]}}$ & $\begin{array}{c}\text { Irrigation } \\
(\mathrm{mm})\end{array}$ & $\begin{array}{c}\text { First } \\
\text { Cutting }\end{array}$ & $\begin{array}{c}\text { Second } \\
\text { Cutting }\end{array}$ & $\begin{array}{c}\text { Third } \\
\text { Cutting }\end{array}$ & $\begin{array}{c}\text { Fourth } \\
\text { Cutting }\end{array}$ \\
\hline 1 & 610 & $137 \mathrm{Bc}$ & $146 \mathrm{Bc}$ & $139 \mathrm{Bc}$ & $167 \mathrm{Ac}$ \\
2 & 380 & $161 \mathrm{Bb}$ & $166 \mathrm{Bbc}$ & $193 \mathrm{Ab}$ & $196 \mathrm{Aab}$ \\
3 & 380 & $157 \mathrm{Bbc}$ & $161 \mathrm{Bbc}$ & $208 \mathrm{Aab}$ & $175 \mathrm{Bbc}$ \\
4 & 200 & $184 \mathrm{Ba}$ & $177 \mathrm{Bab}$ & $216 \mathrm{Aa}$ & $183 \mathrm{Bbc}$ \\
5 & 200 & $174 \mathrm{Bab}$ & $187 \mathrm{Ba}$ & $217 \mathrm{Aa}$ & $210 \mathrm{Aa}$ \\
6 & 0 & $179 \mathrm{Aab}$ & $200 \mathrm{Aa}$ & $\left.{ }_{[} \mathrm{cc}\right]$ & $189 \mathrm{Aabc}$ \\
\hline
\end{tabular}

[a] In treatments 2 and 5, irrigation was applied after green-up and between all cuttings. In treatments 3 and 4, no irrigation was applied between cuttings 2 and 3 .

[b] Different uppercase letters in each row indicate that cutting is significant within the same irrigation treatment averaged across years at $\mathrm{p} \leq$ 0.05 . Different lowercase letters in each column indicate that irrigation treatment is significant within the same cutting averaged across years at $\mathrm{p} \leq 0.05$.

[c] Alfalfa was not harvested at the third cutting due to dry conditions and no regrowth. 
Table 16. Partial budget for center-pivot alfalfa with each irrigation treatment at KSU SWREC near Garden City, Kansas.

\begin{tabular}{|c|c|c|c|c|c|c|}
\hline & \multicolumn{6}{|c|}{ Irrigation Treatment } \\
\hline & 1 & 2 & 3 & 4 & 5 & 6 \\
\hline \multicolumn{7}{|l|}{ Income per hectare } \\
\hline Yield $\left(\mathrm{Mg} \mathrm{ha}^{-1}\right)$ & 15.3 & 12.4 & 11.6 & 8.9 & 8.9 & 4.3 \\
\hline Price $\left(\$ \mathrm{Mg}^{-1}\right)$ & 230 & 260 & 260 & 260 & 260 & 260 \\
\hline Gross returns $\left(\$ h^{-1}\right)$ & 3519 & 3224 & 3016 & 2314 & 2314 & 1118 \\
\hline \multicolumn{7}{|l|}{ Variable costs per hectare ${ }^{[a]}$} \\
\hline Bales (number ha ${ }^{-1}$ ) & 24 & 20 & 18 & 14 & 14 & 7 \\
\hline Bale cost $\left(\$ b^{2} e^{-1}\right)$ & 14 & 14 & 14 & 14 & 14 & 14 \\
\hline Bale cost $\left(\$ h^{-1}\right)$ & 337 & 273 & 256 & 196 & 196 & 95 \\
\hline Irrigation use $\left(\mathrm{mm} \mathrm{ha}^{-1}\right)$ & 610 & 380 & 380 & 200 & 200 & 0 \\
\hline Irrigation cost $\left(\$ \mathrm{~mm}^{-1}\right)$ & 0.21 & 0.21 & 0.21 & 0.21 & 0.21 & 0.21 \\
\hline Irrigation cost $\left(\$ \mathrm{ha}^{-1}\right)$ & 126 & 79 & 79 & 41 & 41 & 0 \\
\hline$P$ use $\left(\mathrm{kg} \mathrm{ha}^{-1}\right)$ & 92 & 74 & 70 & 53 & 53 & 26 \\
\hline$P \operatorname{cost}\left(\$ \mathrm{~kg}^{-1}\right)$ & 1.50 & 1.50 & 1.50 & 1.50 & 1.50 & 1.50 \\
\hline$P \operatorname{cost}\left(\$ h^{-1}\right)$ & 138 & 112 & 104 & 80 & 80 & 39 \\
\hline \multicolumn{7}{|l|}{ Partial budget net return ${ }^{[b]}$} \\
\hline Returns $\left(\$ h^{-1}\right)$ & 2918 & 2760 & 2577 & 1996 & 1996 & 985 \\
\hline es obtair & & & & & & $\begin{array}{l}\text { not } \\
\text { costs }\end{array}$ \\
\hline [b] Excludes some variab & & & & & & \\
\hline
\end{tabular}

costs not affected by irrigation level (Ibendahl et al., 2015). Treatment 1, despite having a slightly lower alfalfa price per $\mathrm{Mg}$, had the highest gross $\left(\$ 3520 \mathrm{ha}^{-1}\right)$ and net $\left(\$ 2920 \mathrm{ha}^{-1}\right)$ returns of all treatments. Treatment 2 had greater net returns than treatment 3 due to more alfalfa yield when irrigation was spread across all treatments, as compared to withholding irrigation between the second and third cuttings when $380 \mathrm{~mm}$ of irrigation was applied. There was no difference in net returns between treatments 4 and 5 or whether or not irrigation was withheld between second and third cuttings when $200 \mathrm{~mm}$ or irrigation was applied. Treatment 6 produced the lowest net returns of all treatments.

\section{DISCUSSION}

Irrigation within most of the South and Central High Plains Aquifer region is unable to meet the full alfalfa crop water requirement. Alfalfa yields in this region are expected to decline as full irrigation shifts to limited irrigation. Averaged across years, dry matter yields were $15.3 \mathrm{Mg} \mathrm{ha}^{-1}$ in treatment $1(610 \mathrm{~mm}), 12.4 \mathrm{Mg} \mathrm{ha}^{-1}$ in treatment $2(380 \mathrm{~mm}$ applied between all cuttings), $11.6 \mathrm{Mg} \mathrm{ha}^{-1}$ in treatment 3 ( $380 \mathrm{~mm}$ and withheld between second and third cuttings), $8.90 \mathrm{Mg} \mathrm{ha}^{-1}$ in treatment $4(200 \mathrm{~mm}$ and withheld between second and third cuttings), $8.9 \mathrm{Mg} \mathrm{ha}^{-1}$ in treatment 5 (200 mm applied between all cuttings), and $4.3 \mathrm{Mg} \mathrm{m}^{-1}$ in treatment 6 (rainfed) (table 17) (Klocke et al., 2013). A study comparing different levels of subsurface drip irrigation found that alfalfa yield was unaffected whether 396 or $586 \mathrm{~mm}$ of irrigation was applied in an environment and soil type similar to this study (Lamm et al., 2012). Yet in the subsurface drip irrigation study, an additional $125 \mathrm{~mm}$ of fall irrigation was applied annually to reduce root intrusion and rodent damage. The difference in alfalfa productivity between these two studies may be due in part to the increased irrigation efficiency of subsurface drip compared to overhead nozzles, and because the subsurface drip irrigation
Table 17. Alfalfa dry matter yields for each cutting and irrigation treatment averaged across years (2008-2011). Complete yield results were presented by Klocke et al. (2013).

\begin{tabular}{ccccccc}
\hline & Total & \multicolumn{5}{c}{ Dry Matter Yield $\left(\mathrm{kg} \mathrm{m}^{-2}\right)^{[\mathrm{b}]}$} \\
\cline { 3 - 7 } Irrigation $_{\text {Treatment }}{ }^{[\mathrm{a}]}$ & $\begin{array}{c}\text { Irrigation } \\
(\mathrm{mm})\end{array}$ & $\begin{array}{c}\text { First } \\
\text { Cutting }\end{array}$ & $\begin{array}{c}\text { Second } \\
\text { Cutting }\end{array}$ & $\begin{array}{c}\text { Third } \\
\text { Cutting }\end{array}$ & $\begin{array}{c}\text { Fourth } \\
\text { Cutting }\end{array}$ & Sum $^{[\mathrm{c}]}$ \\
\hline 1 & 610 & $0.4 \mathrm{a}$ & $0.35 \mathrm{a}$ & $0.4 \mathrm{a}$ & $0.38 \mathrm{a}$ & $1.53 \mathrm{a}$ \\
2 & 380 & $0.35 \mathrm{~b}$ & $0.28 \mathrm{~b}$ & $0.29 \mathrm{~b}$ & $0.32 \mathrm{~b}$ & $1.24 \mathrm{~b}$ \\
3 & 380 & $0.35 \mathrm{~b}$ & $0.31 \mathrm{~b}$ & $0.15 \mathrm{c}$ & $0.36 \mathrm{a}$ & $1.16 \mathrm{~b}$ \\
4 & 200 & $0.26 \mathrm{c}$ & $0.24 \mathrm{c}$ & $0.15 \mathrm{c}$ & $0.24 \mathrm{c}$ & $0.89 \mathrm{c}$ \\
5 & 200 & $0.28 \mathrm{c}$ & $0.21 \mathrm{c}$ & $0.2 \mathrm{~b}$ & $0.21 \mathrm{~d}$ & $0.89 \mathrm{c}$ \\
6 & 0 & $0.21 \mathrm{~d}$ & $0.12 \mathrm{~d}$ & $0 \mathrm{e}$ & $0.1 \mathrm{e}$ & $0.43 \mathrm{~d}$ \\
\hline
\end{tabular}

[a] In treatments 2 and 5, irrigation was applied after green-up and between all cuttings. In treatments 3 and 4, no irrigation was applied between cuttings 2 and 3 .

[b] Different letters in each column indicate that irrigation treatment is significant within the same cutting averaged across years at $\mathrm{p} \leq 0.05$. [c] Sum of cuttings averaged across years by irrigation treatment.

study received additional fall irrigation. The additional fall irrigation likely minimized soil water and alfalfa yield differences between irrigation levels in the subsurface drip study.

This study evaluated the effect of irrigation level, timing, cutting, and weeds on alfalfa forage nutritive values $(\mathrm{CP}$, $\mathrm{ADF}, \mathrm{NDF}, \mathrm{TDN}$, and RFV). In general, applying the highest amount of irrigation (i.e., $610 \mathrm{~mm}$ during the growing season) reduced alfalfa forage nutritive values compared to other irrigation treatments. Other studies have also found that moisture stress increases alfalfa nutritive value (Vough and Marten, 1971; Snaydon, 1972; Carter and Sheaffer, 1983; Harmoney et al., 2013, Peterson et al., 1992). The results from this study suggest that any irrigation level less than full crop requirement improved forage nutritive value and suggest that more research is required on irrigation management near the full crop water requirement to determine if forage nutritive value can be improved while still maintaining full yield. There was a general tendency for improved forage nutritive value at the fourth cutting when irrigation was applied between all cuttings, as compared to withholding irrigation between the second and third cuttings and applying the saved water in addition to the irrigation amount of the first and fourth cuttings. The reduction in forage nutritive value at the fourth cutting (when additional saved irrigation water was applied) was consistent with the forage nutritive value differences found across irrigation amount, where applying more irrigation tended to reduce forage nutritive value. In addition to lower forage nutritive value at the fourth cutting, withholding irrigation between cuttings 2 and 3 reduced total forage yield (treatment 3 ), as compared to applying the irrigation amount equally across all cuttings (treatment 2) (Klocke et al., 2013). To maximize both forage nutritive value and yield, irrigation should be applied all season long and not withheld between the second and third cuttings. Forage nutritive value was lower at the first and second cuttings compared to the third and fourth cuttings when averaged over years and irrigation amount. Irrigation amounts less than full crop requirement increased the forage nutritive value of alfalfa. This increase in forage nutritive value helped offset some of the reduction in forage yield. 


\section{CONCLUSION}

One must consider both alfalfa yield and forage nutritive value when making irrigation and harvest management decisions. Results from this study suggest that forage nutritive value can be improved by using lower amounts of irrigation, at the cost of reduced alfalfa yield and net returns. Currently, supreme grade alfalfa $\left(\$ 290 \mathrm{Mg}^{-1}\right)$ is selling for $10 \%$ more than premium grade $\left(\$ 260 \mathrm{Mg}^{-1}\right)$, and premium grade alfalfa is selling for $12 \%$ more than fair/good grade $\left(\$ 230 \mathrm{Mg}^{-1}\right)$ in southwest Kansas (USDA, 2014). In this study, using the forage nutrient value average across years, treatment 1 , with $610 \mathrm{~mm}$ of irrigation, would have sold for about $\$ 230 \mathrm{Mg}^{-1}$, and all other irrigation treatments would have sold for about $\$ 260 \mathrm{Mg}^{-1}$. This $13 \%$ increase in price did not make up the $19 \%$ yield reduction between treatments 1 and 2, which reduced the net returns by approximately $\$ 158 \mathrm{ha}^{-1}$. Not surprisingly, net returns decreased as irrigation level decreased, but some of this loss can be recovered by maximizing forage nutritive value. Alfalfa producers with lower-capacity wells should consider growing and marketing alfalfa with the highest forage nutritive value possible and using improved irrigation efficiency methods, such as subsurface drip irrigation or mobile drip irrigation. These results suggest that there will be negative economic implications for the region in the future as irrigation pumping capacity declines.

\section{ACKNOWLEDGEMENTS}

This research was supported in part by the Ogallala Aquifer Program, a consortium of the USDA Agricultural Research Service, Kansas State University, Texas AgriLife Research, Texas AgriLife Extension Service, Texas Tech University, and West Texas A\&M University. The authors thank the anonymous reviewers for their constructive comments.

\section{REFERENCES}

Abdul-Jabbar, A. S., Lugg, D. G., Sammis, T. W., \& Gay, L. W. (1985). Relationships between crop water stress index and alfalfa yield and evapotranspiration. Trans. ASAE, 28(2), 454461. http://dx.doi.org/10.13031/2013.32278

Allen, R., Pereira, L. S., Raes, D., \& Smith, M. (1998). Crop evapotranspiration: Guidelines for computing crop water requirements. Irrigation and Drainage Paper No. 56. Rome, Italy: United Nations FAO.

ASABE. (2012). ANSI/ASABE S436.1: Test procedure for determining the uniformity of water distribution of center pivot and lateral move irrigation machines equipped with spray or sprinkler nozzles. St. Joseph, Mich.: ASABE.

Baslam, M., Antolin, M. C., Gogorcena, Y., Muñoz, F., \& Goicoechea, N. (2014). Changes in alfalfa forage quality and stem carbohydrates induced by arbuscular mycorrhizal fungi and elevated atmospheric CO2. Ann. Appl. Biol., 164(2), 190-199. http://dx.doi.org/10.1111/aab.12092

Bolger, T. P., \& Matches, A. G. (1990). Water-use efficiency and yield of sainfoin and alfalfa. Crop Sci., 30(1), 143-148. http://dx.doi.org/10.2135/cropsci1990.0011183X003000010032x

Carter, P. R., \& Sheaffer, C. C. (1983). Alfalfa response to soil water deficits: I. Growth, forage quality, yield, water use, and water-use efficiency. Crop Sci., 23(4), 669-675. http://dx.doi.org/10.2135/cropsci1983.0011183X002300040016x

Collins, M., \& Fritz, J. O. (2003). Forage quality. In R. F. Barnes, C. J. Nelson, K. J. Moore, \& M. Collins (Eds.), Forages: An introduction to grassland agriculture (pp. 363-390). Ames, Iowa: Blackwell.

Fairbourne, M. L. (1982). Water use by forage species. Agron. J., 74(1), 62-66.

http://dx.doi.org/10.2134/agronj1982.00021962007400010018x

Flinn, P. W., Hower, A. A., \& Knievel, D. P. (1990). Physiological response of alfalfa to injury by Empoasca fabae (Homoptera: Cicadellidae). Environ. Entomol. 19(1), 176-181.

http://dx.doi.org/10.1093/ee/19.1.176

Foulds, W. (1978). Response to soil moisture supply in three leguminous species. New Phytol., 80(3), 535-545. http://dx.doi.org/10.1111/j.1469-8137.1978.tb01585.x

Frate, C. A., Roberts, B. A., \& Marble, V. L. (1991). Imposed drought stress has no long-term effect on established alfalfa. California Agric., 45(3), 33-36.

Gifford, R. O., \& Jensen, E. H. (1967). Some effects of soil moisture regimes and bulk density on forage quality in the greenhouse. Agron. J., 59(1), 75-77. http://dx.doi.org/10.2134/agronj1967.00021962005900010023x

Goering, H. K., \& Van Soest, P. J. (1970). Forage fiber analysis: Apparatus, reagents, procedures, and some applications. Agriculture Handbook 379. Washington, D.C.: USDA.

Halim, R. A., Buxton, D. R., Hattendorf, M. J., \& Carlson, R. E. (1989). Water-stress effects on alfalfa forage quality after adjustment for maturity differences. Agron. J., 81(2), 189-194. http://dx.doi.org/10.2134/agronj1989.00021962008100020010x

Hansen, J. L., Miller-Garvin, J. E., Waldron, J. K., \& Viands, D. R. (2002). Comparison of potato leafhopper-resistant and susceptible alfalfa in New York. Crop Sci., 42(4), 1155-1163. http://dx.doi.org/10.2135/cropsci2002.1155

Harmoney, K. R., Lamm, F. R., Johnson, S. K., \& Aboukheira, A. A. (2013). Reducing water inputs with subsurface drip irrigation may improve alfalfa nutritive value. Forage and Grazinglands, 11(1). http://dx.doi.org/10.1094/fg-2013-117-01-rs

Hutchins, S., Buxton, D. R., \& Pedigo, L. P. (1989). Forage quality of alfalfa as affected by potato leafhopper feeding. Crop Sci., 29(6), 1541-1545.

http://dx.doi.org/10.2135/cropsci1989.0011183X002900060046x

Ibendahl, G., O’Brien, D., Haag, L., \& Holman, J. (2015). Centerpivot irrigated alfalfa cost-return budget in western Kansas. Farm Management Guide MF-584. Manhattan, Kans.: Kansas State University.

Kalu, B. A., \& Fick, G. W. (1981). Quantifying morphological development of alfalfa for studies of herbage quality. Crop Sci., 21(2), 267-271.

http://dx.doi.org/10.2135/cropsci1981.0011183X002100020016x

Kincaid, D. C., \& Heerman, D. F. (1974). Scheduling irrigation using a programmable calculator. Publication ARS-NC-12. Washington, D.C.: USDA-ARS.

Klocke, N. L., Currie, R. S., \& Holman, J. D. (2013). Alfalfa response to irrigation from limited water supplies. Trans. ASABE, 56(5), 1759-1768. http://dx.doi.org/10.13031/trans.56.10166

Klocke, N. L., Hunter Jr., C., \& Alam, M. (2003). Application of a linear-move sprinkler system for limited irrigation research. ASAE Paper No. 032012. St. Joseph, Mich.: ASAE.

Lamm, F. R., Harmoney, K. R., Aboukheira, A. A., \& Johnson, S. K. (2012). Alfalfa production with subsurface drip irrigation in the central Great Plains. Trans. ASABE, 55(4), 1203-1212. http://dx.doi.org/10.13031/2013.42258

Lamm, F. R., Rogers, D. H., \& Manges, H. L. (1994). Irrigation scheduling with planned soil water depletion. Trans. ASAE, 37(5), 1491-1497. http://dx.doi.org/10.13031/2013.28232

Lofgreen, G. P. (1953). The estimation of total digestible nutrients from digestible organic matter. J. Animal Sci., 12(2), 359-365.

Marten, G. C., Ehle, F. R., \& Ristau, E. A. (1987). Performance and 
photosensitization of cattle related to forage quality of four legumes. Crop Sci., 27(1), 138-145.

http://dx.doi.org/10.2135/cropsci1987.0011183X002700010033x

Peterson, P. R., Sheaffer, C. C., \& Hall, M. H. (1992). Drought effects on perennial forage legume yield and quality. Agron. J., 84(5), 774-779.

http://dx.doi.org/10.2134/agronj1992.00021962008400050003x

Retta, A., \& Hanks, R. J. (1980). Corn and alfalfa production as influenced by limited irrigation. Irrig. Sci., 1(3), 135-147. http://dx.doi.org/10.1007/bf00270878

Rohweder, D. A., Barnes, R. F., \& Jorgensen, N. (1978). Proposed hay grading standards based on laboratory analysis for evaluating quality. J. Animal Sci., 47(3), 747-759.

Smith, D., Bula, R. J., \& Walgenbach, R. P. (1986). Forage management (5th ed.). Dubuque, Iowa: Kendall/Hunt.

Snaydon, R. W. (1972). The effect of total water supply, and frequency of application, upon Lucerne: II. Chemical composition. Australian J. Agric. Res., 23(2), 253-256. http://dx.doi.org/10.1071/AR9720253
Stroh, J. R., Carleton, A. E., \& Seamands, W. J. (1972). Management of Lutana cicer milkvetch for hay, pasture, seed, and conservation uses. Laramie, Wyo.: University of Wyoming Agricultural Experiment Station.

Sulc, R. M., Johnson, K. D., Sheaffer, C., Undersander, D. J., \& van Santen, E. (2004). Forage quality of potato leafhopper resistant and susceptible alfalfa cultivars. Agron. J., 96(2), 337-343. http://dx.doi.org/10.2134/agronj2004.3370

Temme, D. G., Harvey, R. G., Fawcett, R. S., \& Young, A. W. (1979). Effects of annual weed control on alfalfa forage quality. Agron. J., 71(1), 51-54. http://dx.doi.org/10.2134/agronj1979.00021962007100010012x

USDA. (2014). Kansas hay market report. Washington, D.C.: USDA. Retrieved from www.ams.usda.gov/mnreports/dc_gr310.txt

Vough, L. R., \& Marten, G. C. (1971). Influence of soil moisture and ambient temperature on yield and quality of alfalfa forage. Agron. J., 63(1), 40-42.

http://dx.doi.org/10.2134/agronj1971.00021962006300010014x 